\title{
COVID-19 VACCINATION INCLUDING 198 PATIENTS WITH HISTORY OF SEVERE ANAPHYLACTIC REACTION - OWN OBSERVATIONS
}

\author{
SZCZEPIENIE PRZECIW COVID-19 198 PACJENTÓW Z CIĘŻKĄ REAKCJĄ \\ ANAFILAKTYCZNĄ W WYWIADZIE - OBSERWACJE WŁASNE
}
${ }^{1}$ Department of Infectious Diseases and Paediatrics, Stefan Żeromski Specialized Hospital in Kraków, Poland Oddział Chorób Infekcyjnych i Pediatrii, Szpital Specjalistyczny im. Stefana Żeromskiego w Krakowie
${ }^{2}$ Andrzej Frycz Modrzewski Krakow University
Krakowska Akademia im. Andrzeja Frycza Modrzewskiego

\begin{abstract}
INTRODUCTION. The SARS-CoV-2 pandemic has taken a heavy toll of 4 million deaths. We were all looking forward to the authorisation of safe vaccines. Soon after vaccination programmes started, the reports about anaphylaxis began to emerge. Growing anxiety has urged regulatory agencies and academic societies to issue adequate recommendations regarding patient eligibility to vaccination.

AIM OF THE STUDY. Observation of patients who had a history of a severe anaphylactic reaction and/or anaphylactic shock and were vaccinated against COVID-19.

MATERIAL AND METHODS. A single-centre, prospective, observational study was conducted at the Department of Infectious Diseases and Paediatrics at Stefan Żeromski Specialist Hospital in Krakow, Poland. Adult patients with a history of a severe anaphylactic reaction and/or anaphylactic shock and patients without it were administered the Comirnaty vaccine by Pfizer-BioNTech or the ChAdOx1-S vaccine by AstraZeneca in a two-dose schedule at the department. The patients were then observed at the department for 60 minutes. A week after each vaccination dose, the patients were contacted by telephone in order to collect data about a late allergic reaction.

RESULTS. In total, 403 patients were enrolled. For the Pfizer BioNTech Comirnaty vaccine, the study group (i.e. patients with a history of severe anaphylactic reactions to various substances, other than those present in the vaccine) included 151 patients, and there were 161 controls. For the AstraZeneca ChAdOx1-S vaccine, the study group included 47 patients, and 44 patients formed the control group.

Nine cases of severe anaphylactic reactions were reported: 3 in the study groups (1.5\%) and 6 in the control groups (3\%). Anaphylactic shock after vaccine administration occurred in one patient from the control group.

CONCLUSIONS. COVID-19 vaccination with using Pfizer-BioNTech Comirnaty and AstraZeneca ChAdOx1-S is safe also for patients with a history of a severe anaphylactic reaction and/or anaphylactic shock. Severe anaphylactic reactions and anaphylactic shock, although rare, may also develop in patients without a prior history of allergic conditions. The Personnel od vaccination centres should be therefore trained to provide medical help. Incorrect patient exclusions delay the attainment of the goal determined for the vaccination programme.
\end{abstract}

Key words: COVID-19, vaccination, anaphylaxis, anaphylactic shock

\section{STRESZCZENIE}

WSTĘP. Pandemia SARS-CoV-2 pochłonęła ponad 4 miliony ofiar. Z niecierpliwością czekaliśmy na wprowadzenie do użytku skutecznych szczepień ochronnych. Wkrótce po ich rozpoczęciu zaczęły pojawiać się raporty przypadków anafilaksji. Rosnący niepokój zmusił agencje regulacyjne i towarzystwa naukowe do wydania stosownych zaleceń dotyczących kwalifikacji do szczepień.

CEL PRACY. Obserwacje osób szczepionych przeciwko COVID-19 obciążonych wywiadem ciężkiej reakcji anafilaktycznej i/lub wstrząsu anafilaktycznego. 
MATERIAŁY I METODYKA. W Oddziale Chorób Infekcyjnych i Pediatrii Szpitala Specjalistycznego im. Stefana Żeromskiego w Krakowie zostało przeprowadzone jednoośrodkowe, prospektywne badanie obserwacyjne. Dorosłym pacjentom z wywiadem ciężkiej reakcji anafilaktycznej i/lub wstrząsu anafilaktycznego oraz bez takiego wywiadu podano szczepionkę Pfizer-BioNTech Comirnaty lub AstraZeneca ChAdOx1-S w schemacie dwudawkowym w warunkach oddziału. Pacjenci byli następnie obserwowani w oddziale przez okres 60 min. Po tygodniu od podania każdej dawki szczepionki kontaktowano się z pacjentami telefonicznie celem zebrania wywiadu odnośnie do opóźnionej reakcji alergicznej.

WYNIKI. Do badania zostało zakwalifikowanych łącznie 403 pacjentów: dla szczepionki Pfizer BioNTech Comirnaty grupa badana (osoby z wywiadem ciężkiej reakcji anafilaktycznej po różnych substancjach, innych niż zawarte w szczepionce) stanowiła 151 osób oraz grupa kontrolna 161 osób, natomiast dla szczepionki AstraZeneca ChAdOx1-S grupa badana 47 osób oraz grupa kontrolna 44 osoby.

Zaraportowano 9 przypadków ciężkich reakcji alergicznych, z czego $3 \mathrm{w}$ grupach badanych (1,5\%) i $6 \mathrm{w}$ grupach kontrolnych (3\%). Wstrząs anafilaktyczny po podaniu szczepionki wystąpił u jednego pacjenta w grupie kontrolnej.

WNIOSKI. Szczepienia przeciwko COVID-19 szczepionkami Pfizer BioNTech oraz AstraZeneca ChAdOx1-S są bezpieczne również dla pacjentów z wywiadem ciężkiej reakcji anafilaktycznej i/lub wstrząsu anafilaktycznego. Ciężka reakcja anafilaktyczna i wstrząs anafilaktyczny, choć rzadkie, mogą wystąpić również u pacjentów bez wcześniejszego wywiadu schorzeń alergicznych, dlatego personel w punktach szczepień powinien zostać odpowiednio przeszkolony w zakresie udzielania pomocy medycznej. Nieprawidłowe dyskwalifikacje opóźniają osiągnięcie zakładanego celu programu szczepień.

Slowa kluczowe: COVID-19, szczepienia, anafilaksja, wstrzas anafilaktyczny

\section{INTRODUCTION}

The outbreak of the pandemic caused by SARSCoV-2 in 2019 has so far taken a toll of over 4 million deaths (1). The pandemic has ruthlessly exposed the preparation status of the health care systems all around the world, causing their collapse in various situations. Unfortunately, the promising publications about clinical efficacy and safety of vaccines (2) were faced with concern and social resistance.

Vaccination is considered to be the best way to prevent infectious diseases (3). The benefits concern not only the vaccinated individuals, but also unvaccinated ones due to the phenomenon of herd immunity (4).

On 8 December 2020, the United Kingdom (UK) began the prevention programme using PfizerBioNTech Comirnaty, and subsequently, on 4 January 2021, also with AstraZeneca ChAdOx1-S. As soon as the next day, the UK authorities confirmed 2 anaphylaxis cases (5). Several days later, the American Centers for Disease Control and Prevention (CDC) reported further 6 cases in the United States (6). On 24 January 2021, the British Medicines and Healthcare Products Regulatory Agency (MHRA) published a report on 101 cases of anaphylaxis or anaphylactoid reactions following the administration of Pfizer-BioNTech Comirnaty and 13 cases after using AstraZeneca ChAdOx1-S that had been reported via the Coronavirus Yellow Card Scheme (7). On 16 March 2021, another report appeared describing 47 cases after the first dose of Pfizer-BioNTech Comirnaty

\section{WSTEP}

Wybuch pandemii wywołanej przez SARS-CoV-2 w 2019 roku pochłonął do dnia dzisiejszego ponad 4 miliony ofiar (1). Pandemia bezwzględnie obnażyła stan przygotowania systemu opieki zdrowotnej w krajach na całym świecie, w wielu sytuacjach doprowadzając do jego załamania się. Niestety, obiecujące publikacje o bezpieczeństwie i skuteczności klinicznej szczepionek (2) spotkały się z obawą i oporem społecznym.

Szczepienia ochronne są uważane za najlepszą formę profilaktyki chorób zakaźnych (3). Korzyści przekładają się nie tylko na osoby zaszczepione, lecz także na osoby niezaszczepione w mechanizmie odporności grupowej (4). 8 grudnia 2020 roku Wielka Brytania (UK) rozpoczęła profilaktykę szczepionką Pfizer -BioNTech Comirnaty, a następnie 4 stycznia 2021 roku także szczepionką AstraZeneca ChAdOx1-S. Już następnego dnia władze Wielkiej Brytanii potwierdziły 2 przypadki anafilaksji (5). Kilka dni później Amerykańskie Centrum Kontroli i Prewencji Chorób (CDC) zgłosiło kolejnych 6 przypadków w Stanach Zjednoczonych Ameryki (USA) (6). 24 stycznia 2021 roku Brytyjska Agencja Regulacji do spraw Leków i Opieki Zdrowotnej (MHRA) upubliczniła raport zawierający 101 przypadków anafilaksji lub reakcji anafilaktoidalnej po szczepionce Pfizer-BioNTech Comirnaty oraz 13 przypadków po szczepionce AstraZeneca ChAdOx1-S, zgłoszonych poprzez system raportowania Coronavirus Yellow Card Scheme (7). 16 marca 
reported via the Vaccine Adverse Event Reporting System (VAERS) (8).

According to the MHRA's statement of 30 December, the only absolute contraindication to vaccination is hypersensitivity to the active substance or to any other excipient listed in the Summary of Product Characteristics (9). Even so, it is relatively common in practice to consider patients ineligible to be vaccinated due to a history of anaphylactic shock in reaction to certain substances, such as drugs, foods or insect bites.

Up to 4 August 2021, the MHRA received reports of 453 cases of vaccine adverse events associated with an anaphylactic or anaphylactoid reaction to Pfizer-BioNTech Comirnaty and 803 cases related to AstraZeneca ChAdOx1-S (10).

In Poland, over 18 million people had been fully vaccinated up to 12 August 2021, which translates to a total of over 35 million administered vaccines (including the first and the second doses) (11). Based on the current report on vaccine adverse events, there have been 128 cases of severe allergic reactions or anaphylactic shock in Poland $(0.36 / 100,000)(12)$.

\section{AIM}

The article presents our experience regarding COVID-19 vaccination in patients with a prior history of a severe anaphylactic reaction and/or anaphylactic shock in comparison to a group of patients without such a history.

\section{MATERIAL AND METHODS}

A single-centre, prospective, observational study was conducted at the Department of Infectious Diseases and Paediatrics at Stefan Żeromski Specialized Hospital in Krakow, Poland. Patients with a history of a severe anaphylactic reaction and/ or anaphylactic shock were scheduled to receive twodose COVID-19 vaccination with Pfizer-BioNTech Comirnaty or AstraZeneca ChAdOx1-S at the hospital department. According to expert guidelines and recommendations of academic societies, the only absolute contraindication to COVID-19 vaccination is an immediate systemic allergic reaction:

1. after the administration of the previous dose of a COVID-19 vaccine, and

2. to any excipient of the vaccine (particularly polyethylene glycol or polysorbate 80) (13).

According to the recommendations, patients with a prior anaphylactic reaction to other substances can receive vaccination.

Moreover, control groups were created for patients vaccinated with Pfizer-BioNTech or AstraZeneca
2021 roku ukazał się raport opisujący 47 przypadków po pierwszej dawce Pfizer-BioNTech Comirnaty zgłoszonych poprzez system raportowania Vaccine Adverse Event Reporting System (VAERS) (8).

Zgodnie ze stanowiskiem MHRA, wydanym 30 grudnia, za jedyne przeciwwskazanie bezwzględne do podania szczepionki uznaje się nadwrażliwość na substancję czynną lub którąkolwiek substancję pomocniczą wymienioną w Charakterystyce Produktu Leczniczego (9). Mimo tego w praktyce zdarzają się liczne przypadki dyskwalifikacji ze szczepień osób z wywiadem wstrząsu anafilaktycznego po takich substancjach jak leki, pokarmy lub użądleniach owadów.

Do dnia 4 sierpnia 2021 roku MHRA otrzymała zgłoszenia o 453 przypadkach niepożądanych reakcji poszczepiennych związanych z reakcją anafilaktyczną lub anafilaktoidalną po szczepionce Pfizer-BioNTech Comirnaty oraz 803 po szczepionce AstraZeneca ChAdOx1-S (10).

W Polsce na dzień 12 sierpnia 2021 roku więcej niż 18 milionów osób zostało w pełni zaszczepionych, sumarycznie wykonano ponad 35 milionów szczepień (pierwsza i druga dawka łącznie) (11). Jak wynika z Bieżącego Raportu Niepożądanych Odczynów Poszczepiennych, w skali kraju odnotowano 128 niepożądanych odczynów poszczepiennych w postaci ciężkiej reakcji alergicznej lub wstrząsu anafilaktycznego $(0,36 / 100000)(12)$.

\section{CEL PRACY}

W artykule publikujemy własne obserwacje szczepień przeciwko COVID-19 osób obciążonych wywiadem ciężkiej reakcji anafilaktycznej i/lub wstrząsu anafilaktycznego, w porównaniu z grupą osób bez takiego wywiadu.

\section{MATERIAŁ I METODY}

W Oddziale Chorób Infekcyjnych i Pediatrii Szpitala Specjalistycznego im. Stefana Żeromskiego w Krakowie zostało przeprowadzone jednoośrodkowe, prospektywne badanie obserwacyjne. Pacjenci z wywiadem ciężkiej reakcji anafilaktycznej i/lub wstrząsu anafilaktycznego zostali skierowani do podania szczepionki przeciwko COVID-19 w schemacie dwudawkowym preparatami: Pfizer-BioNTech Comirnaty lub AstraZeneca ChAdOx1-S, w warunkach oddziału szpitalnego. Zgodnie z wytycznymi ekspertów oraz rekomendacjami towarzystw naukowych jedynym bezwzględnym przeciwwskazaniem do podania szczepionki przeciwko COVID-19 jest uogólniona reakcja alergiczna typu natychmiastowego po:

1. podaniu poprzedniej dawki szczepionki przeciwko COVID-19 oraz 
ChAdOx1-S. Group allocation was random with restrictions imposed by the ministerial National Programme for COVID-19 Vaccination. Patients over 18 years of age were recruited. Pregnant and breastfeeding women were excluded. For the PfizerBioNTech product, the anticipated dose interval was between 21 and 35 days depending on the ministerial recommendations at that time and other independent causes, for example ineligibility due to an ongoing infection. For AstraZeneca ChAdOx1-S, the anticipated dose interval was 77 days.

According to the guidelines of the Polish Society of Allergology, patients with a history of a severe allergic reaction or anaphylactic shock should be monitored for 30 minutes after each dose (14). In our study, the patients from both the study and control groups were monitored for 60 minutes after each dose. A week after each vaccination dose, each patient from both the study and control groups was contacted by telephone in order to collect data about a potential late allergic reaction. Any untoward symptoms that occurred during the monitoring at the Department or within a week after the dose were evaluated in terms of a potential allergic reaction. The vaccination took place at a treatment room at the hospital department, with all precautions and with intensive care unit (ICU) facilities.

For determining patient eligibility, the following definitions of the European Academy of Allergy and Clinical Immunology were adopted:

- Anaphylaxis is a serious, life-threatening, sytemic hypersensitivity reaction characterised by a rapid onset of breathing difficulties, circulatory problems and gastrointestinal disorders. It is usually associated with skin or mucosal lesions.

- Anaphylactic shock is a severe, rapidly developing anaphylactic reaction (anaphylaxis) with lifethreatening blood pressure drop (15).

The patients were divided into 4 groups:

- A1. The study group receiving Pfizer-BioNTech Comirnaty

- A2. The study group receiving AstraZeneca ChAdOxl-S

- B1. The control group receiving Pfizer-BioNTech Comirnaty

- B2. The control group receiving AstraZeneca ChAdOx1-S.

The patients gave written consent to participate in the study. The study was approved by the Ethics Committee of the Regional Chamber of Physicians in Krakow; resolution No 19/KBL/OIL/ of 12 February 2021. The principles of Good Clinical Practice and the Declaration of Helsinki were observed.

The study group consisted of randomly selected persons who, in the initial screening history
2. jakimkolwiek składniku szczepionki (zwłaszcza glikolu polietylenowym lub polisorbacie 80) (13).

Zgodnie z rekomendacjami u pacjentów z reakcją anafilaktyczną po innych substancjach $\mathrm{w}$ wywiadzie można wykonać szczepienie.

Utworzono również grupy kontrolne dla pacjentów szczepionych szczepionkami Pfizer-BioNTech lub AstraZeneca ChAdOx1-S. Przydział do grupy był losowy z ograniczeniami narzuconymi przez ministerialny Narodowy Program Szczepień Przeciw COVID-19. Do badania zostały zrekrutowane osoby powyżej 18 . roku życia. Z badania zostały wykluczone kobiety ciężarne i karmiące piersią. Dla szczepionki Pfizer-BioNTech przewidziany odstęp wynosił między 21 a 35 dni pomiędzy dawkami w zależności od obowiązujących w danym czasie zaleceń ministerialnych oraz innych niezależnych przyczyn, np. dyskwalifikacji ze względu na trwającą infekcję. Dla szczepionki AstraZeneca ChAdOx1-S przewidywany odstęp wynosił 77 dni pomiędzy dawkami.

Według Wytycznych Polskiego Towarzystwa Alergologii pacjenci z wywiadem ciężkiej reakcji alergicznej lub wstrząsu anafilaktycznego powinni być obserwowani przez okres 30 min po każdej dawce (14). W naszym badaniu pacjenci zarówno grupy badanej, jak i kontrolnej byli obserwowani przez okres $60 \mathrm{~min}$ po każdej dawce. Po tygodniu od podania każdej dawki z każdym z pacjentów grupy badanej i kontrolnej nawiązano kontakt telefoniczny celem zebrania wywiadu na temat możliwej opóźnionej reakcji alergicznej. Jakiekolwiek niepożądane objawy w trakcie obserwacji na Oddziale lub w okresie tygodnia od podania dawki były oceniane pod kątem możliwości wystąpienia reakcji alergicznej. Szczepienia odbywały się w gabinecie zabiegowym oddziału szpitalnego z zachowaniem wszelkich środków ostrożności oraz zapleczem Oddziału Intensywnej Opieki Medycznej (OIOM).

W celach kwalifikacyjnych przyjęto następujące definicje European Academy of Allergy and Clinical Immunology:

- Anafilaksja to ciężka, zagrażająca życiu uogólniona reakcja nadwrażliwości, charakteryzująca się nagłym wystąpieniem zaburzeń oddychania, krążenia oraz ze strony przewodu pokarmowego, zwykle związana z pojawieniem się zmian na skórze lub błonach śluzowych.

- Wstrząs anafilaktyczny to ciężka, szybko rozwijająca się reakcja anafilaktyczna (anafilaksja), w której występuje obniżenie ciśnienia tętniczego zagrażające życiu (15).

Pacjenci zostali podzieleni na 4 grupy:

- A1. Grupa badana zaszczepiona szczepionką Pfizer-BioNTech Comirnaty

- A2. Grupa badana zaszczepiona szczepionką AstraZeneca ChAdOx1-S 
questionnaire for vaccination, gave a positive answer about a systemic allergic reaction (anaphylactic shock) and negative answers to the remaining questions (16). This means that the group included patients with a history of a severe anaphylactic reaction or anaphylactic shock following food ingestion, administration of drugs and other medical devices as well as insect bites, thus meeting the criteria of level 1 and 2 of the Brighton Collaboration Case Definition (17). Patient assignment to the study group was preceded with careful verification of the medical history and confirmed with medical records if such records could be obtained.

The control group consisted of randomly selected persons out of the 52127 ones who registered at the vaccination centre at the hospital and in the screening history questionnaire filled in prior to vaccination, selected all negative answers (16). This means that none of these patients had a prior history of severe anaphylactic reactions or anaphylactic shock.

The study endpoint was the occurrence of a vaccine adverse event in the mechanism of an allergic reaction within 7 days after the first and second dose of vaccination. Vaccine adverse events were classified based on the criteria of the Brighton Collaboration Case Definition (17). The management implemented in the case of an adverse allergic event was based on the protocol recommended by the European Academy of Allergy and Clinical Immunology (18).

The study data were compared using the $\chi^{2}$ and Mann-Whitney tests. The results were expressed as number (percentage) or mean (standard deviation), unless specified otherwise. Probability values below 0.05 were considered statistically significant. The calculations were performed in MedCalc Statistical Software, version 14.12.0 (MedCalc Software bvba, Ostend, Belgium; http://www.medcalc.org; 2014).

\section{RESULTS}

Our hospital has been conducting the COVID-19 vaccination programme since 27 December 2020. In total, 403 patients were enrolled in the study: group A1: 151 patients, group A2: 47 patients, group B1: 161 patients and group B2: 44 patients. Patient demographics are presented in Table I. The difference between the number of women in the study and control groups for both vaccines was statistically significant.

Figure 1 presents agents that caused prior severe anaphylactic reactions or anaphylactic shock in patients from the study groups (A1 and A2). These severe reactions were usually caused by antibiotics, followed by insect bites and non-steroidal antiinflammatory drugs (NSAIDs). Six patients reported severe reactions to more than one agent.
- B1. Grupa kontrolna zaszczepiona szczepionką Pfizer-BioNTech Comirnaty

- B2. Grupa kontrolna zaszczepiona szczepionką AstraZeneca ChAdOx1-S.

Uczestnicy wyrazili pisemną zgodę na udział w badaniu. Uzyskano zgodę Komisji Bioetyki przy Okręgowej Izbie Lekarskiej w Krakowie nr 19/KBL/OIL/ z dnia 12 lutego 2021 roku. Badanie zostało przeprowadzone z zachowaniem Zasad Dobrej Praktyki Klinicznej oraz Deklaracji Helsińskiej.

Grupa badana składała się z losowo wybranych osób, które w kwestionariuszu wstępnego wywiadu przesiewowego przed szczepieniem zakreśliły pytania o ciężką, uogólnioną reakcję alergiczną (wstrząs anafilaktyczny) pozytywnie oraz pozostałe odpowiedzi negatywne (16). Oznacza to, że do tej grupy zostali zrekrutowani pacjenci z wywiadem ciężkiej reakcji anafilaktycznej lub wstrząsu anafilaktycznego po spożyciu pokarmu, podaniu leków i innych wyrobów medycznych lub ukąszeniu przez owada spełniający kryteria Brighton Collaboration Case Definition poziomu pierwszego i drugiego (17). Przydzielenie pacjenta do grupy badanej było poprzedzone dokładną weryfikacją wywiadu medycznego oraz potwierdzone dokumentacją medyczną, w przypadkach, gdy taką dokumentację uzyskano.

Grupa kontrolna składała się z losowo wybranych osób spośród 52 127, które zgłosiły się do Punktu Szczepień działającego w szpitalu i które w kwestionariuszu wstępnego wywiadu przesiewowego przed szczepieniem zakreśliły wszystkie odpowiedzi negatywne (16). Oznacza to, że u żadnej z tych osób w wywiadzie nie stwierdzono ciężkiej reakcji anafilaktycznej lub wstrząsu anafilaktycznego.

Końcowym punktem badania było wystąpienie niepożądanego odczynu poszczepiennego w mechanizmie reakcji alergicznej w przeciągu 7 dni od podania pierwszej oraz drugiej dawki szczepionki. Zaklasyfikowanie niepożądanego odczynu poszczepiennego odbywało się w oparciu o kryteria Brighton Collaboration Case Definition (17). W razie wystąpienia niepożądanej reakcji alergicznej wdrożono postępowanie zgodne z protokołem zalecanym przez Europejską Akademię Alergologii i Immunologii Klinicznej (18).

Celem porównania uzyskanych w badaniu danych posługiwano się testami $\chi^{2}$ oraz Mann-Whitney. Wyniki zostały zaprezentowane jako liczba (procent) lub średnia (odchylenie standardowe), jeżeli nie zostało wskazane inaczej. Wartość prawdopodobieństwa poniżej 0,05 została uznana jako statystycznie istotna. Do obliczeń użyto programu MedCalc Statistical Software version 14.12.0 (MedCalc Software bvba, Ostend, Belgium; http://www.medcalc.org; 2014). 
Table I. Demographic characteristics of patients

Tabela I. Charakterystyka demograficzna grup klinicznych

\begin{tabular}{|c|c|c|c|}
\hline Group & $\begin{array}{c}\text { Pfizer- } \\
\text { BioNTech } \\
\text { Comirnaty } \\
\text { (A1) } \\
\text { N=151 }\end{array}$ & $\begin{array}{c}\text { Pfizer- } \\
\text { BioNTech } \\
\text { Comirnaty } \\
\text { (B1) } \\
\text { N=161 }\end{array}$ & P value \\
\hline Women, n (\%) & $119(78.8)$ & $97(60.25)$ & $\mathbf{0 . 0 0 0 4}^{\text {a }}$ \\
\hline $\begin{array}{c}\text { Age, years, } \\
\text { mean (SD) } \\
\text { median }\end{array}$ & $\begin{array}{c}54.2(14.7) \\
56.0\end{array}$ & $\begin{array}{c}55.4(17.7) \\
56.0\end{array}$ & $0.2758^{\mathrm{b}}$ \\
\hline $\begin{array}{c}\text { AstraZeneca } \\
\text { ChAdOx1-S }\end{array}$ & $\begin{array}{c}\text { AstraZeneca } \\
\text { ChAdOx1-S } \\
(\mathbf{A 2})\end{array}$ & P value \\
(B2) & \\
\hline Women, n (\%) & $39(83.0)$ & $22(50.0)$ & $\mathbf{0 . 0 0 0 8}^{\mathrm{a}}$ \\
\hline $\begin{array}{c}\text { Age, years, } \\
\text { mean (SD) }\end{array}$ & $53.9(12.6)$ & $53.4(13.0)$ & $0.4565^{\mathrm{b}}$ \\
median & 57.0 & 60.0 & \\
\hline
\end{tabular}

${ }^{\mathrm{a}} \chi^{2}$ test, ${ }^{\mathrm{b}}$ Mann-Whitney test

$\mathrm{SD}$ - standard deviation

Bold text indicates a statistically significant difference

Apart from untoward symptoms described as typical after COVID-19 vaccination, several mild allergic reactions were reported during the observation at the Department and within the first 24 hours following vaccination. These reactions were classified as non-threatening and not requiring any medical intervention. Most of them were described by the patients as a slight itching and scratching sensation in the throat and mild shortness of breath.

Five persons refused the second dose of the vaccine (3 in Group A1 and 2 in Group A2). One person from group A1 died shortly after receiving the vaccine. This was a case of sudden cardiac death that occurred 2 weeks after the first dose of Pfizer-BioNTech Comirnaty and was assessed as unrelated with the vaccine. In total, 9 cases of anaphylactic reactions were reported, three of which were classified as severe anaphylactic reactions and one as anaphylactic shock that required intramuscular adrenaline (Table II). The patient with anaphylactic shock was a man aged 41 with no additional comorbidities. He had not reported any prior allergic reactions to medications, foods, insect bites or other vaccines. It ended with full recovery. In the study group, there were 3 reactions in the form of urticaria ( 2 cases after Pfizer-BioNTech Comirnaty and 1 case after AstraZeneca ChAdOx1-S). In the control group, there were 2 reactions in the form of urticaria (after Pfizer-BioNTech Comirnaty) and 3 severe anaphylactic reactions ( 2 after Pfizer-BioNTech Comirnaty and 1 after AstraZeneca ChAdOx1-S).

\section{WYNIKI}

Od 27 grudnia 2020 roku na terenie naszego szpitala odbywają się szczepienia przeciwko COVID-19. Do badania zostało zakwalifikowanych łącznie 403 pacjentów: w grupie A1 - 151 osób, w grupie A2 - 47 osób, w grupie B1 - 161 osób i w grupie B2 - 44 osoby. Charakterystyka demograficzna grup klinicznych została przedstawiona w Tabeli I. Różnica między liczbą kobiet w grupie badanej i kontrolnej w przypadku obydwu szczepionek była istotna statystycznie.

Na Rycinie 1 przedstawiono czynniki będące przyczyną ciężkiej reakcji anafilaktycznej lub wstrząsu anafilaktycznego $\mathrm{w}$ wywiadzie medycznym pacjentów grup badanych (A1 i A2). Najczęściej ciężkie reakcje były wywoływane u pacjentów przez antybiotyki, a na kolejnych miejscach także ukąszenia owadów i niesteroidowe leki przeciwzapalne (NLPZ). 6 pacjentów zgłosiło ciężkie reakcje po więcej niż jednym czynniku.

Podczas obserwacji w Oddziale oraz w ciągu pierwszych 24 godzin po szczepieniu oprócz objawów niepożądanych opisanych jako typowe po szczepieniu przeciwko COVID-19 raportowano kilka przypadków łagodnych reakcji alergicznych, które zostały zaklasyfikowane jako niezagrażające i tym samym niewymagające interwencji medycznej. Większość z nich była opisywana przez pacjentów jako nieznaczne uczucie świądu i drapania w gardle oraz łagodne uczucie duszności.

Przyjęcia drugiej dawki szczepionki odmówiło 5 osób (3 w grupie A1 oraz 2 w grupie A2). Jedna osoba w grupie A1 zmarła w niedługim czasie po podaniu szczepionki. Zgon nastąpił w wyniku nagłej śmierci sercowej około 2 tygodni po pierwszej dawce szczepionki Pfizer-BioNTech Comirnaty i według ustaleń nie miał związku z jej podaniem.

Łącznie zaraportowano 9 przypadków reakcji anafilaktycznych, z czego 3 zaklasyfikowano jako ciężką reakcję anafilaktyczną oraz jedną jako wstrząs anafilaktyczny wymagający podaży adrenaliny domięśniowo (Tabela II). Pacjent, u którego wystąpił wstrząs, to mężczyzna w wieku 41 lat bez dodatkowych obciążeń chorobowych. W wywiadzie medycznym nie podawał reakcji alergicznych po lekach, pokarmach, ukąszeniach owadów oraz innych szczepieniach. Zdarzenie zakończyło się pełnym wyzdrowieniem. W grupie badanej obserwowano 3 reakcje w postaci pokrzywki (2 po podaniu szczepionki Pfizer-BioNTech Comirnaty oraz 1 po szczepionce AstraZeneca ChAdOx1-S). Natomiast w grupie kontrolnej obserwowano 2 reakcje w postaci pokrzywki (po podaniu szczepionki Pfizer -BioNTech Comirnaty) oraz 3 ciężkie reakcje anafilaktyczne (2 po podaniu szczepionki Pfizer-BioNTech Comirnaty oraz 1 po podaniu szczepionki AstraZene- 


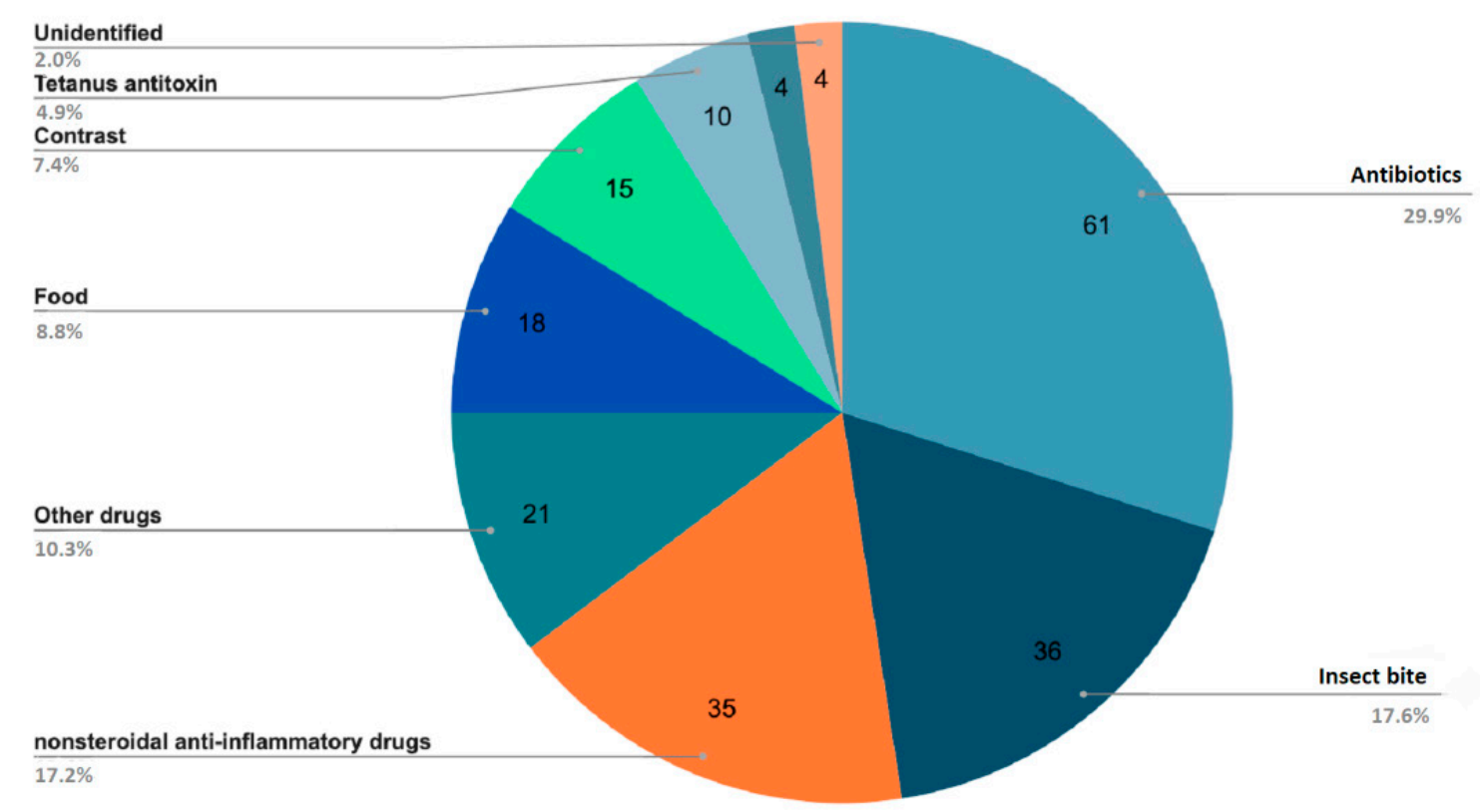

Figure 1. Etiological factors of anaphylaxis and anaphylactic shock in patients with medical history of severe allergic reaction and/or anaphylactic shock

Rycina 1. Czynniki będące przyczyną ciężkiej reakcji alergicznej oraz wstrząsu anafilaktycznego w wywiadzie medycznym pacjentów

Severe anaphylactic reactions and urticarias appeared during the first several hours after vaccination.

The patients with severe anaphylactic reactions initially reported significant oedema of the face and upper body, followed by dyspnoea and dysphagia. Two patients required steroid administration. The anaphylactic shock patient lost consciousness within several seconds after the administration of the first dose; blood pressure was $90 / 60 \mathrm{mmHg}$. The patient immediately received intramuscular adrenaline, as is the standard management, after which he regained consciousness and was further observed in the Hospital Emergency Department. During the observation, the patient did not report any alarming symptoms and was discharged several hours later. After 7 days, the patient ca ChAdOx1-S). Ciężkie reakcje alergiczne oraz pokrzywki wystąpiły w ciągu kilku godzin po szczepieniu.

Pacjenci, u których zaraportowano ciężkie reakcje anafilaktyczne, zgłaszali początkowo znaczny obrzęk w okolicach twarzy i górnej części ciała, do którego następnie dołączyła się duszność oraz zaburzenia połykania. Dwa przypadki wymagały podaży sterydów. Osoba ze wstrząsem anafilaktycznym straciła przytomność w ciągu kilkunastu sekund po podaniu pierwszej dawki szczepionki, zmierzone ciśnienie wynosiło 90/60 mmHg. Pacjent otrzymał natychmiast adrenalinę domięśniowo zgodnie ze standardem, po której odzyskał przytomność i trafił na dalszą obserwację w ramach Szpitalnego Oddziału Ratunkowego.

Table II. Reported cases of allergic reaction

Tabela II. Zaraportowane przypadki reakcji alergicznych

\begin{tabular}{|c|c|c|c|c|}
\hline Allergic reaction & $\begin{array}{c}\text { Pfizer-BioNTech } \\
\text { Comirnaty (A1) }\end{array}$ & $\begin{array}{c}\text { AstraZeneca } \\
\text { ChAdOx1-S (A2) }\end{array}$ & $\begin{array}{c}\text { Pfizer-BioNTech } \\
\text { Comirnaty (B1) }\end{array}$ & $\begin{array}{c}\text { AstraZeneca } \\
\text { ChAdOx1-S (B2) }\end{array}$ \\
\hline Urticaria n/N(\%) & $2 / 151(1.3)$ & $1 / 47(2.1)$ & $2 / 161(1.2)$ & 0 \\
\hline $\begin{array}{c}\text { Severe anaphylactic } \\
\text { reaction n/N (\%) }\end{array}$ & 0 & 0 & $2 / 161(1.2)$ & $1 / 44(2.3)$ \\
\hline $\begin{array}{c}\text { Anaphilactic shock } \\
\text { n/N (\%) }\end{array}$ & 0 & 0 & $1 / 161(0.6)$ & 0 \\
\hline Total & $2 / 151(1.3)$ & $1 / 47(2.1)$ & $5 / 161(3.1)$ & $1 / 44(2.3)$ \\
\hline
\end{tabular}

A1. The group vaccinated with Pfizer-BioNTech Comirnaty

A2. The group vaccinated with AstraZeneca ChAdOx1-S

B1. The control group vaccinated with Pfizer-BioNTech Comirnaty

B2. The control group vaccinated with AstraZeneca ChAdOx1-S 
was contacted by telephone, and a late allergic reaction was ruled out. The patient was considered ineligible to receive the second dose of the same vaccine (mRNA).

\section{DISCUSSION}

Anaphylaxis is estimated to occur in $0.05-2 \%$ of the population and is more common in young individuals (19). Approximately $10 \%$ of anaphylactic reactions have the form of anaphylactic shock with blood pressure drop, and about $2 \%$ are fatal (20).

Of 198 patients referred to the Department for vaccination because of a history of anaphylactic shock, 151 received Pfizer-BioNTech Comirnaty and 47 received AstraZeneca ChAdOx1-S, as allocated by the National Vaccination Programme. Most of the patients in the study and control groups were women, which correlates with the fact that anaphylaxis tends to be more common in women aged over 15 years. This tendency persists up to the elderly age, when these gender-based differences disappear (21).

Almost $2 / 3$ of the prior cases of severe anaphylactic reactions and anaphylactic shock in the study group were caused by antibiotics, insect bites and nonsteroidal anti-inflammatory drugs. Our findings are in line with the data reported by other authors (21). Food reactions are more common in the paediatric population (22), and that is why they were noted in our study only for $8.8 \%$ of cases. Vaccination is a relatively rare cause of anaphylaxis (23), in our study accounting for only $2 \%$ of cases.

Anaphylactic reactions following vaccination in general are estimated to develop in 1.31 (95\% CI, $0.90-1.84$ ) cases per one million doses (23). According to the available data, anaphylaxis with the mRNA vaccines is estimated to occur in 2-5 cases per one million doses (24). In Poland, in the period covered by the study, according to the data of the Ministry of Health, 128 vaccine adverse events were reported per 35 million doses of COVID-19 vaccines administered (3.7 per million) (25). In the present study on a group of 403 people, we observed 3 anaphylactic reactions and 1 anaphylactic shock, which indicates a much higher frequency of anaphylactic reactions than in the available reports. Such reactions also occurred in the control group, without a history of severe anaphylactic reaction or anaphylactic shock, so it can be assumed that not all adverse events following COVID-19 vaccination were reported. The frequency and severity of adverse events following COVID-19 vaccinations require further studies in larger groups of people.

As other drugs and medical devices, vaccines can potentially cause anaphylactic reactions. Fortunately, most reported cases of adverse events are not lifethreatening and are not even caused by an immune
Podczas obserwacji pacjent nie zgłaszał niepokojących dolegliwości, został zwolniony po kilku godzinach obserwacji do domu. Po 7 dniach kontaktowano się z pacjentem telefonicznie, wykluczono opóźnioną reakcję alergiczną. Pacjent został zdyskwalifikowany z podania drugiej dawki tej samej szczepionki (mRNA).

\section{DYSKUSJA}

Częstość anafilaksji szacuje się na 0,05-2\% populacji i częściej występuje wśród młodych osób (19). W około $10 \%$ przypadków reakcja anafilaktyczna przebiega pod postacią wstrząsu anafilaktycznego ze spadkiem ciśnienia tętniczego, a około $2 \%$ kończy się zgonem (20).

Spośród 198 pacjentów skierowanych do szczepienia w warunkach oddziału ze względu na wstrząs anafilaktyczny w wywiadzie 151 pacjentów zostało zaszczepionych szczepionką Pfizer-BioNTech Comiranty oraz 47 AstraZeneca ChAdOx1-S zgodnie z przydziałem Narodowego Programu Szczepień. Zarówno w grupie badanej, jak i kontrolnej przeważała liczba kobiet, co koreluje odpowiednio z tendencją do częstszego występowania anafilaksji u kobiet w wieku powyżej 15 lat. Tendencja ta utrzymuje się aż do wieku starczego, w którym nie ma już różnic między płciami (21).

Prawie $2 / 3$ przypadków ciężkich reakcji anafilaktycznych i wstrząsów anafilaktycznych w wywiadzie pacjentów z grupy badanej było spowodowane antybiotykami, ukąszeniami owadów i niesteroidowymi lekami przeciwzapalnymi. Nasze wyniki pokrywają się z danymi prezentowanymi przez innych autorów (21). Reakcje pokarmowe występują częściej w populacji dziecięcej (22), dlatego w naszym badaniu odpowiadały jedynie za $8,8 \%$ przypadków. Szczepienia są stosunkowo rzadką przyczyną reakcji anafilaktycznych (23), w naszym badaniu stanowiły jedynie $2 \%$ przypadków.

Częstość reakcji anafilaktycznych występujących po szczepieniach ogółem jest szacowana na 1,31 (95\% CI, 0,90-1,84) przypadków na milion podanych dawek (23). Według obecnie dostępnych danych częstość reakcji anafilaktycznych po szczepieniach mRNA występuje z częstością 2-5 na milion podanych dawek (24). W Polsce w czasie objętym badaniem wg danych Ministerstwa Zdrowia zgłoszono 128 niepożądanych odczynów poszczepiennych (NOP) na $35 \mathrm{mln}$ podanych dawek szczepionek przeciw COVID-19 (3,7 na milion) (25). W przeprowadzonym badaniu w grupie 403 osób obserwowaliśmy 3 reakcje anafilaktyczne i 1 wstrząs anafilaktyczny, co wskazuje na znacznie większą częstość reakcji anafilaktycznych niż w dostępnych raportach. Reakcje takie wystąpiły również w grupie osób bez obciążającego wywiadu, można 
reaction (26). Vaccine antigens very rarely provoke anaphylaxis, and most reactions are caused by excipients, such as egg protein, gelatine and other substances. Of the marketed vaccines, the one that causes anaphylactic reactions most frequently is the inactivated trivalent influenza vaccine (TIV) (23).

The mechanism of anaphylaxis with COVID-19 vaccines has not been unequivocally identified and requires further research (27). The suspected excipients are polyethylene glycol (PEG 2000) in Pfizer-BioNTech Comirnaty and its related polysorbate 80 (also known under code E433) in AstraZeneca ChAdOx1-S. Polyethylene glycol (also called macrogol) is commonly used as a component of drugs, household agents and cosmetics (28). Polysorbate 80 can be found in food products, drugs, including monoclonal antibodies, and marketed vaccines, for example DTap, HepB, HPV, pneumococcal conjugate vaccine, influenza vaccine and herpes zoster vaccine $(25,29)$. Moreover, the literature describes 2 cases of patients with cross-reactivity between polyethylene glycol and polysorbate 80 (30).

Limitations. Patients who wanted to receive COVID-19 vaccination were more inclined to choose our hospital because of their significant history of anaphylactic reactions or anaphylactic shock, and because they had been rejected at other vaccination centres. Because of the long period of time that had passed since the prior anaphylactic reaction, medical records regarding these events were not available for all patients.

The type of vaccine administered to the patient was assigned by the system of the National Vaccination Programme.

\section{CONCLUSIONS}

COVID-19 vaccination with Pfizer-BioNTech Comirnaty and AstraZeneca ChAdOx1-S is safe also for patients with a history of severe anaphylactic reactions and/or anaphylactic shock, and these patients should not be excluded from vaccination programmes.

Severe anaphylactic reactions and anaphylactic shock following vaccination are rare, but may develop also in patients without a prior positive history of allergic conditions. The personnel of each vaccination centre should be therefore adequately trained in terms of the management procedures.

Every effort should be made to conduct COVID-19 vaccination in patients with a history of anaphylactic reactions to products that are different from vaccine components as improper exclusions may impede the attainment of the pre-specified goal of the vaccination programme. więc przypuszczać, że nie wszystkie niepożądane odczyny poszczepienne po szczepieniach przeciw COVID-19 są zgłaszane. Częstość i ciężkość reakcji poszczepiennych po szczepieniach przeciwko COVID-19 wymagają dalszych badań na większych grupach osób.

Szczepionki, podobnie jak inne leki i wyroby medyczne, mogą być potencjalnie przyczyną reakcji anafilaktycznych. Na szczęście większość zgłaszanych przypadków reakcji niepożądanych nie stanowi zagrożenia życia pacjenta oraz nie jest nawet spowodowana reakcją immunologiczną (26). Antygeny szczepionkowe bardzo rzadko są przyczyną reakcji anafilaktycznych, większość jest spowodowana reakcją na komponenty takie jak białko jaja, żelatyna oraz inne substancje. Spośród dostępnych na rynku szczepionek reakcje anafilaktyczne najczęściej powoduje trójwalentna inaktywowana szczepionka przeciwko grypie (TIV) (23).

Mechanizm reakcji anafilaktycznej występującej po szczepionkach przeciwko COVID-19 nie został jeszcze jednoznacznie zidentyfikowany i wymaga dalszych badań (27). Podejrzanymi czynnikami są glikol polietylenowy (PEG 2000) stanowiący składnik szczepionki Pfizer-BioNTech Comirnaty oraz spokrewniony polisorbat 80 (występujący też pod nazwą kodową E433) zawarty w szczepionce AstraZeneca ChAdOx1-S. Glikol polietylenowy (znany również jako makrogol) jest powszechnie stosowany jako składnik leków, artykułów gospodarstwa domowego oraz kosmetyków (28). Polisorbat 80 można znaleźć w produktach spożywczych, lekach, w tym przeciwciałach monoklonalnych i dostępnych na rynku szczepionkach, np. DTap, HepB, HPV, skojarzonej szczepionce pneumokokowej, szczepionce przeciwko grypie oraz przeciwko wirusowi Herpes Zoster $(25,29)$. Ponadto w literaturze zostały opisane 2 przypadki pacjentów z alergią krzyżową pomiędzy glikolem polietylenowym i polisorbatem 80 (30).

Ograniczenia badania. Osoby chcące się zaszczepić przeciwko COVID-19 chętniej wybierały nasz Szpital ze względu na obciążający wywiad ciężkiej reakcji anafilaktycznej lub wstrząsu anafilaktycznego oraz dyskwalifikację w innych punktach szczepień. Ze względu na odległy czas od momentu wystąpienia reakcji anafilaktycznej w przeszłości nie u wszystkich pacjentów było możliwe uzyskanie dokumentacji dotyczącej tego zdarzenia. Rodzaj szczepionki podawanej pacjentowi był przydzielany przez system Narodowego Programu Szczepień. 
The observed frequency of severe anaphylactic reactions following COVID-19 vaccines may indicate incomplete reporting of vaccine adverse events, including allergic reactions.

\section{REFERENCES}

1. World Health Organization. COVID-19 Weekly Epidemiological Update. World Health Organisation. 2021, https://www.who.int/docs/ default-source/coronaviruse/situation-reports/ weekly_epidemiological_update_22.pdf

2. Polack FP, Thomas SJ, Kitchin N et al. Safety and Efficacy of the BNT162b2 mRNA Covid-19 Vaccine. N Engl J Med. 2020;383(27):2603-15.

3. Sachs J. Protecting the public's health: Critical functions of the section 317 immunization program-A report of the national vaccine advisory committee. Public Health Rep. 2013;128(2):78-95.

4. Lefebvre CDS, Terlinden A, Standaert B. Dissecting the indirect effects caused by vaccines into the basic elements. Hum Vaccines Immunother. 2015;11(9):2142-57.

5. Mahase E. Covid-19: Pfizer and BioNTech submit vaccine for US authorisation. BMJ. 2020;371(December):m4552.

6. Clark T. Anaphylaxis Following m-RNA COVID-19 Vaccine Receipt. 2020. https://www. cdc.gov/vaccines/acip/meetings/downloads/ slides-2020-12/slides-12-19/05-COVID-CLARK. pdf

7. Torjesen I. Covid-19: Norway investigates 23 deaths in frail elderly patients after vaccination. BMJ. 2021;372(February):n149.

8. Shimabukuro TT, Cole M, Su JR. Reports of Anaphylaxis after Receipt of mRNA COVID-19 Vaccines in the US-December 14, 2020-January 18, 2021. JAMA - J Am Med Assoc. 2021;325(11):11012.

9. Glover RE, Urquhart R, Lukawska $J$ et al. Vaccinating against covid-19 in people who report allergies. BMJ. 2021;372:16-7.

10. MHRA - Medicines \& Healthcare products Regulatory Agency. Coronavirus vaccine weekly summary of Yellow Card reporting. 2021. https://www.gov.uk/government/publications/ coronavirus-covid-19-vaccine-adverse-reactions/ coronavirus-vaccine-summary-of-yellow-cardreporting\#yellow-card-reports

11. COVID-19 vaccination report. https://www.gov. pl/web/szczepimysie/raport-szczepien-przeciwkocovid-19

12. Current report on vaccine adverse events. https:// www.gov.pl/web/szczepimysie/niepozadaneodczyny-poszczepienne

\section{WNIOSKI}

Szczepienie przeciw COVID-19 szczepionką Pfizer -BioNTech Comirnaty oraz AstraZeneca ChAdOx1-S jest bezpieczne również dla pacjentów z ciężką reakcją anafilaktyczną i/lub wstrząsem anafilaktycznym w wywiadzie i nie powinni być oni dyskwalifikowani ze szczepień.

Ciężka reakcja anafilaktyczna i wstrząs anafilaktyczny po podaniu szczepionki występuje rzadko, ale może wystąpić również u pacjentów bez obciążającego wywiadu w zakresie schorzeń alergicznych i w każdym punkcie wykonującym szczepienia personel powinien zostać odpowiednio przeszkolony w zakresie procedur postępowania.

Należy dołożyć wszelkich starań do przeprowadzenia szczepień przeciw COVID-19 u pacjentów z wywiadem reakcji anafilaktycznej po produktach innych niż składniki szczepionki, gdyż nieprawidłowe dyskwalifikacje ze szczepienia zagrażają osiągnięciu zakładanego celu programu szczepień.

Zaobserwowana częstość reakcji anafilaktycznych po szczepieniach przeciwko COVID-19 może wskazywać na niepełne zgłaszanie niepożądanych odczynów poszczepiennych, w tym reakcji alergicznych.

13. Summary Document for Interim Clinical Considerations Summary Document for Interim Clinical Considerations. 2021;1-2. https://www. cdc.gov/vaccines/covid-19/clinical-considerations/ covid-19-vaccines-us.html\#

14. Kruszewski J, Cichocka-Jarosz E, Czarnobilska E et al. Recommendations of the Polish Society of Allergology on the qualification of person with allergies and anaphylaxis to vaccination against COVID-19. Alergol Pol - Polish J Allergol. 2021;8(1):1-8

15. Muraro A, Roberts G, Worm M et al. Anaphylaxis: Guidelines from the European Academy of Allergy and Clinical Immunology. Allergy Eur J Allergy Clin Immunol. 2014;69(8):1026-45.

16. Initial screening history questionnaire for COVID-19 vaccination in adults. 2021;(version 1):4-5. https://www.gov.pl/attachment/f165d7e264e8-41c0-99a7-275719ac5131

17. Rüggeberg JU, Gold MS, Bayas JM et al. Anaphylaxis: Case definition and guidelines for data collection, analysis, and presentation of immunization safety data. Vaccine. 2007;25(31):5675-84.

18. Sokolowska M, Eiwegger $T$, Ollert $M$ et al. EAACI statement on the diagnosis, management and prevention of severe allergic reactions to COVID-19 vaccines. Allergy. 2021. 0-2. 
19. Simons FER. Anaphylaxis. J Allergy Clin Immunol. 2010;125(2 SUPPL. 2):18-23.

20. Kruszewski J, Cichocka-Jarosz E, Błażowski Ł. Anafilaksja i wstrząs anafilaktyczny u dzieci. Med Prakt Pediatr 2021;136:61-71

21. Lieberman $\mathrm{P}$, Camargo CA, Bohlke $\mathrm{K}$ et al. Epidemiology of anaphylaxis: Findings of the American College of Allergy, Asthma and Immunology Epidemiology of Anaphylaxis Working Group. Ann Allergy, Asthma Immunol. 2006;97(5):596-602.

22. Sicherer SH, Muñoz-Furlong A, Burks AW, Sampson HA. Prevalence of peanut and tree nut allergy in the US determined by a random digit dial telephone survey. J Allergy Clin Immunol. 1999;103(4):559-62.

23. McNeil MM, DeStefano F. Vaccine-associated hypersensitivity. J Allergy Clin Immunol. 2018;141(2):463-72.

24. Selected Adverse Events Reported after COVID-19 Vaccination. 2021;15-7. https://www.cdc.gov/ coronavirus/2019-ncov/vaccines/safety/adverseevents.html\#print

25. NOP - niepożądany odczyn poszczepienny. Szczepienie przeciwko COVID-19 - Portal Gov.pl (www.gov.pl)

26. Caubet JC, Ponvert C. Vaccine Allergy. Immunol Allergy Clin North Am. 2014;34(3):597-613.

27. Kounis NG, Koniari I, de Gregorio C et al. Allergic reactions to current available covid-19 vaccinations: Pathophysiology, causality, and therapeutic considerations. Vaccines. 2021;9(3):1-19.
28. Banerji A, Wickner PG, Saff $R$ et al. mRNA Vaccines to Prevent COVID-19 Disease and Reported Allergic Reactions: Current Evidence and Suggested Approach. J Allergy Clin Immunol Pract. 2021 Apr 1;9(4):1423-37.

29. Turner PJ, Ansotegui IJ, Campbell DE et al. COVID-19 vaccine-associated anaphylaxis: A statement of the World Allergy Organization Anaphylaxis Committee. World Allergy Organ J. 2021;14(2):100517.

30. Stone CA, Liu Y, Relling M V. et al. Immediate Hypersensitivity to Polyethylene Glycols and Polysorbates: More Common Than We Have Recognized. J Allergy Clin Immunol Pract [Internet]. 2019;7(5):1533-1540.e8.

\section{Received: 08.09.2021}

Accepted for publication: 06.11.2021

Otrzymano: 08.09.2021 r.

Zaakceptowano do publikacji: 06.11.2021 r.

\section{Address for correspondence:}

Adres do korespondencji:

Lidia Stopyra

Oddział Chorób Infekcyjnych i Pediatrii

Szpitala Specjalistycznego im. S. Żeromskiego

w Krakowie

Os. Na Skarpie 67, 31-913 Kraków

Tel.: (48) 126229503

E-mail: lidiastopyra@gmail.com 